\title{
The Pulsatility of ACTH Secretion in the Rat Anterior Pituitary Cell Perifusion System
}

\author{
Qiong Denga Zeng Zhang ${ }^{\mathrm{a}, \mathrm{b}}$ Yong Wu $\mathrm{Wu}^{\mathrm{a}, \mathrm{c}}$ \\ aGuangdong and Shenzhen Key Laboratory of Male Reproductive Medicine and Genetics, Institute \\ of Urology, Peking University Shenzhen Hospital, Shenzhen PKU-HKUST Medical Center, Shenzhen, \\ ${ }^{\mathrm{b} G}$ Graduate School, Anhui Medical University, Hefei, 'Graduate School, Guangzhou Medical University, \\ Guangzhou, China
}

\author{
Key Words \\ Anterior Pituitary $\bullet$ ACTH $\bullet$ Pulsatility $\bullet \mathrm{CRH} \bullet \mathrm{AVP}$
}

\begin{abstract}
Aims: This study aimed to examine the physiological mechanism whereby the corticotropinreleasing hormone $(\mathrm{CRH})$ and arginine vasopressin (AVP) exert their influence on adrenocorticotropic hormone (ACTH) secretion in pituitary cells. Methods: Anterior pituitary cells were harvested from male rats and placed in the perifusion system. Cells were perifused with serum-free medium for 6 hours before fraction collection. After 30-minute of baseline collection, perifusion media was changed to expose the cells to $\mathrm{CRH}$ with or without AVP. ACTH concentration in each fraction was measured using enzyme immunoassay chemiluminescent kit. Results: The lowest physiological concentration of CRH (10 pM) or AVP (10 pM) was not able to induce a marked increase in ACTH secretion. Higher concentration of CRH (30 pM) or AVP (100 pM) in the physiological range caused sustained elevation of ACTH secretion $(P<0.001)$, while the secretion remained at similar levels for up to 1 hour with continuous stimulation. Perifusion with $10 \mathrm{pM}$ AVP and $10 \mathrm{pM}$ or $30 \mathrm{pM} \mathrm{CRH}$ caused a 2.38-fold and 2.99-fold increase in pulsatile ACTH secretion in pituitary cells, respectively. The duration of pulsatility caused by perifusion with $10 \mathrm{pM}$ AVP and $30 \mathrm{pM} \mathrm{CRH}$ was close to that observed under physiological condition. Conclusions: By using the rat anterior pituitary cell perifusion system, we found that CRH and AVP potentiate the effect of each other on ACTH secretion, but AVP was a less potent agonist than $\mathrm{CRH}$. The data suggest that $\mathrm{CRH}$ and AVP are essential for the pulsatility of $A C T H$, and AVP acts like a switch of the pulsatility.

\section{Introduction}

The hypothalamic-pituitary-adrenal (HPA) axis is an important component of the endocrine system. It is involved in controlling stress response and has an important physiological role in regulating digestion, the immune system, emotions and moods, sexual behavior and energy storage and consumption. The hypothalamus synthesizes corticotropin- 


\section{Cellular Physiology Cell Physiol Biochem 2017;41:154-162

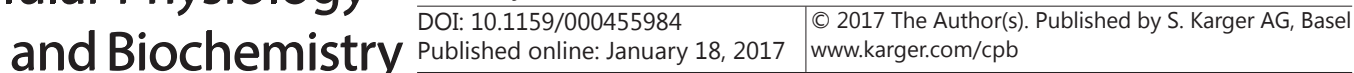 \\ Deng/Zhang/Wu: ACTH Pulsatility In Vitro}

releasing hormone (CRH) as well as arginine vasopressin (AVP), which are released into the pituitary portal circulation and reach corticotroph cells in the pituitary gland, where they stimulate the secretion of adrenocorticotropic hormone (ACTH) into the peripheral circulation $[1,2]$. The main target of ACTH action is the zona fasciculata of the adrenal cortex, where it stimulates the production and secretion of glucocorticoids. When the glucocorticoids concentration reaches sufficiently high levels, it will in turn inhibit the HPA axis activity by restraining the expression and secretion of CRH and AVP in the hypothalamus and inhibiting ACTH secretion and the transcription of its precursor protein, proopiomelanocortin (POMC). Glucocorticoids are important for normal metabolic activity and essential for adaption to stress [3].

In this study, a rat pituitary cell perifusion system was developed to study the key role of the pituitary gland in the HPA axis. Hypothalamic CRH and AVP released into the pituitary portal circulation gain access to receptors in the anterior pituitary corticotroph, where they stimulate ACTH secretion. CRH is a potent stimulant of ACTH secretion [4] and POMC transcription in vitro and in vivo [5]. The corticotroph of crhr1 gene knockout mice is not able to synthesize and release ACTH [6]. In contrast, AVP, on its own, is a weaker stimulator of ACTH secretion, but it markedly potentiates the stimulatory effect of CRH on ACTH secretion $[7,8]$. The number of AVP receptor $1 \mathrm{~B}(\mathrm{~V} 1 \mathrm{~b})$ is closely related with the response to stress [9]. In contrast to $\mathrm{CRH}, \mathrm{AVP}$ does not stimulate POMC transcription on its own or in combination with CRH. Moreover, in vivo and in vitro studies have shown an inhibitory effect of AVP on POMC transcription [10].

A deconvolution analysis of frequent sampling reveals that ACTH is secreted in pulses, with $40 \pm 1.5$ pulses measured per 24 hours [11], which is not entirely due to pulsatile CRH release. Light mediates the circadian rhythm of ACTH secretion by activating the transcription of the PER1 gene, which can alter the specific structure of chromatin and the accessibility to genes destined for transcription [12]. AVP may be responsible for the modulation of ACTH pulses, a study has revealed a circadian rhythm in AVP RNA expression and the loss of the circadian rhythm of AVP RNA expression was shown in transgenic CLOCK knockout mice [13]. Here in this study, we proposed that physiological concentration of CRH and AVP are able to stimulate pituitary cells in vitro to secret ACTH in a pulstatility, this also suggested that the pulsatility of ACTH secretion is not controlled by hypothalamus.

\section{Materials and Methods}

\section{Animals}

Male Sprague Dawley rats weighing approximately $250 \mathrm{~g}$ were exposed to light for 16 hours per day over five days before use. Euthanasia was performed by decapitation after $\mathrm{CO}_{2}$ sedation, and pituitary glands were rapidly removed and collected in ice-cold M199 medium (Gibco).

\section{Cell culture}

Pituitary glands were minced and transferred to a $50 \mathrm{ml}$ tube (BD Falcon) and washed with buffer 1 (calcium- and magnesium-free Dulbecco's PBS, containing $2 \mathrm{mM} \mathrm{L-glutamine,} 1.26 \mathrm{mM} \mathrm{CaCl}_{2}$ and $0.3 \%$ $\mathrm{BSA})$. After a 15 -minutes incubation in a water bath at $37^{\circ} \mathrm{C}$ with shaking $(60 \mathrm{rpm})$ in $10 \mathrm{ml}$ trypsin solution (buffer 1 containing $4 \mathrm{mg} / \mathrm{mL}$ trypsin). Next,10 ml of buffer 1 containing $10 \mu \mathrm{g}$ of deoxyribonuclease I (Sigma) were added and the tube was kept on ice for 1 minute. The supernatant was replaced with $5 \mathrm{ml}$ of buffer 1 containing trypsin inhibitor $(2-2.5 \mathrm{mg} / \mathrm{mL})$, and the tissue was incubated at $37^{\circ} \mathrm{C}$ for 5 minutes. After a two steps wash with 2 mM EDTA for 5 minutes and 1 mM EDTA for 10 minutes, pituitary cells were mechanically dispersed by repeated gentle pipetting in buffer 1 until all cells were released. Cells were collected by centrifugation at $200 \times \mathrm{g}$ for 10 minutes and re-suspended in serum-free M199 at a density of 1.5 million cells/mL with Cytodex I micro-carriers (GE Healthcare). Cells were transferred to a $37^{\circ} \mathrm{C}$ cell incubator under $5 \% \mathrm{CO}_{2}-95 \%$ air. Before the addition of the serum and antibiotics, cells were gently shaken every 30 minutes for 2 hours to avoid clamping. 


\section{Cellular Physiology Cell Physiol Biochem 2017;41:154-162 \begin{tabular}{ll|l} 
and Biochemistry Published online: January 18, 2017 & $\begin{array}{l}\text { (c) } 2017 \text { The Author(s). Published by S. Karger AG, Basel } \\
\text { www.karger.com/cpb }\end{array}$
\end{tabular} \\ Deng/Zhang/Wu: ACTH Pulsatility In Vitro}

\section{Perifusion}

Rat anterior pituitary cells cultured on Cytodex beads were transferred into $0.5 \mathrm{ml}$ perifusion chambers (Acusyst-S Cellex Biosciences).and then were perifused for 6 hours with basic perifusion medium (M199 medium containing $0.1 \% \mathrm{BSA}$ ) at $37^{\circ} \mathrm{C}$. Every 5-minute fraction was collected as a sample in $5 \mathrm{ml}$ polypropylene tubes containing $50 \mu \mathrm{l}$ collection medium ( $500 \mathrm{mM}$ EDTA and $4000 \mathrm{kIU} / \mathrm{ml}$ aprotinin). Before the treatments, six samples (30 minutes) were collected as baseline control, the samples were immediately placed in dry ice and then stored in $-80^{\circ} \mathrm{C}$.

\section{ACTH measurement}

The ACTH concentration was measured using the ACTH chemiluminescence ELISA kit (Phoenix Pharmaceuticals Corporation). The standard curve was adjusted as follows: $10 \mathrm{ng} / \mathrm{ml}, 33 \mathrm{ng} / \mathrm{ml}, 100 \mathrm{ng} / \mathrm{ml}$, $330 \mathrm{ng} / \mathrm{ml}$. Samples were thawed out and diluted with basic perifusion medium. We followed the protocol provided by the manufacturer of the kit to calculated the ACTH concentration.

\section{Statistical analysis}

The data are presented as the mean \pm SEM. The statistical significance of the differences between the groups was determined by an independent $t$-test or one/two-way analysis of variance (ANOVA), followed by a Fisher's protected least-significant difference post-hoc test unless otherwise indicated. Statistical significance was set at $p<0.05$.

\section{Results}

Effects of CRH or AVP pulses on ACTH secretion in column perifused rat anterior pituitary cells

In this study, rat anterior pituitary cells were kept in perifusion columns perifused with the estimated basal pituitary portal circulation levels of CRH (Bachem) [14, 15] and AVP (Bachem) [15]. Neither the lowest physiological concentration of CRH (10 pM) nor that of AVP (10 pM) was able to cause noticeable increase in ACTH secretion. However, increasing concentration of AVP significantly stimulated ACTH secretion $(p<0.001,1.94 \pm 0.08$-fold by $100 \mathrm{pM}$ and $2.36 \pm 0.14$-fold by $1 \mathrm{nM}$ ). Thirty picomolars of CRH increased ACTH secretion by $1.99 \pm 0.14$-fold, whereas a higher concentration of $100 \mathrm{pM}$ increased it by $6.99 \pm 0.22$ fold, but secretion started to decline 15 minutes after continuous perifusion . (Fig. 1).

Fig. 1. Effects of CRH or AVP pulses on ACTH secretion in anterior pituitary cells. Cells were perifused with serum-free medium before the stimulation. After $30 \mathrm{mi}$ nutes of collection of the baseline samples $(n=6)$, cells received another 30-minutes stimulation of perifusion medium with different concentrations of AVP (A) or $\mathrm{CRH}(\mathrm{B})$.The data represent the average of the ACTH values with or without stimulus, expressed as mean \pm SEM.**, $p<0.001$.

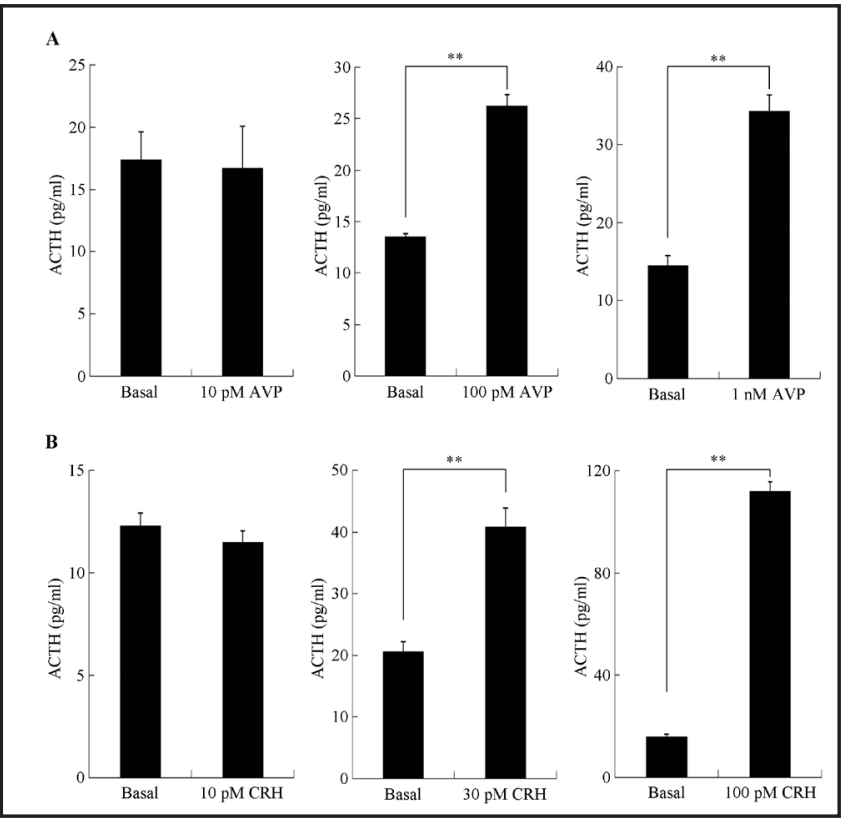


Effect of AVP on ACTH secretion stimulated by 30 pM CRH in anterior pituitary cells

To test the dose-response effect of AVP on ACTH secretion stimulated by $30 \mathrm{pM} \mathrm{CRH,}$ rat anterior pituitary cells were perifused with different doses of AVP at 30-minute-interval. Consistent with the previous data, with a combination of $30 \mathrm{pM}$ CRH and $10 \mathrm{pM}$ AVP produced about 2.80-fold increase in ACTH secretion. A hundred picomolars AVP caused a 3.99-fold increase and the highest concentration $1 \mathrm{nM}$ increase ACTH secretion by 6.40-fold. (Fig. 2).

Effect of the combination of CRH and 10pM AVP on ACTH secretion in anterior pituitary cells

To determine the effect of the lowest physiological concentration of AVP on the CRHstimulated ACTH secretion, rat pituitary cells were subjected to continuous perifusion with 10 pM AVP together with CRH. The results, shown in Fig. 3, revealed that a combination of $10 \mathrm{pM}$ CRH and $10 \mathrm{pM}$ AVP produced a $2.38 \pm 0.09$-fold increase in ACTH secretion, while the higher concentration of CRH (30 pM) in combination with $10 \mathrm{pM}$ AVP increased the ACTH secretion by $2.99 \pm 0.10$-fold.

\section{Effect of AVP on CRH-stimulated ACTH secretion in anterior pituitary cells}

Noteworthy, we found that a pulsatile ACTH secretion in anterior pituitary cells receiving constant $10 \mathrm{pM}$ CRH and $10 \mathrm{pM}$ AVP, which is consistent with the reported physiological condition $[14,15]$. We repeated this experiments, and found the duration of the pulsatility

Fig. 2. Effect of AVP on ACTH secretion stimulated by $30 \mathrm{pM}$ CRH in anterior pituitary cells. Cells were perifused with serum-free medium before the stimulation. After collection of the baseline samples $(n=6)$, cells received constant stimulation with perifusion medium containing 30 pM CRH. Three 10-minute pulses of AVP were added 30 minutes later, at 30-minutes interval. The time periods of the perifusion with $\mathrm{CRH}$ and AVP are shown by the clear-dotted and gray-dotted boxes.

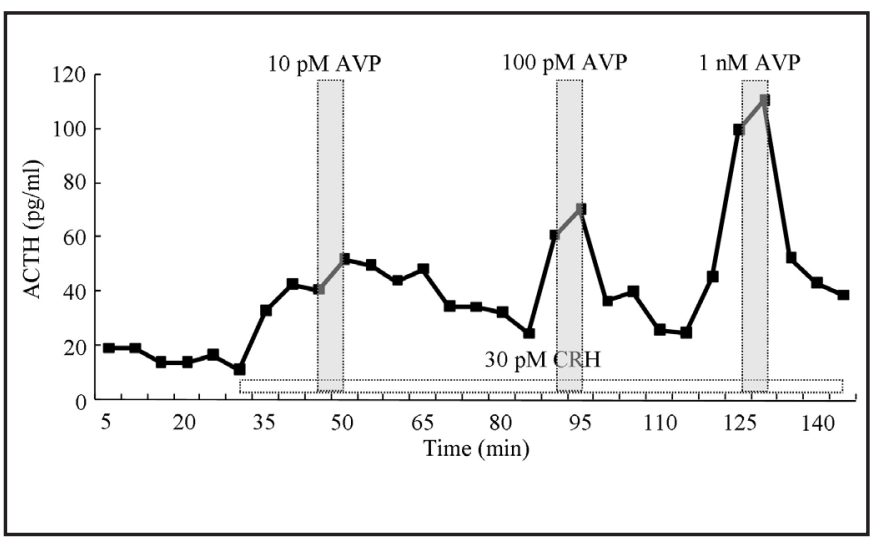

Fig. 3. Effect of the combination of $\mathrm{CRH}$ and $10 \mathrm{pM}$ AVP on ACTH secretion in anterior pituitary cells. Cells were perifused with serum-free medium before stimulation. After 30 minutes of collection of the baseline samples $(n=6)$, cells received another 30-minutes stimulation with perifusion medium containing different concentrations of $\mathrm{CRH}$ and $10 \mathrm{pM}$ AVP. The data represent the average of the ACTH values with or without stimulus, expressed as mean \pm SEM.**, $p<0.001$.

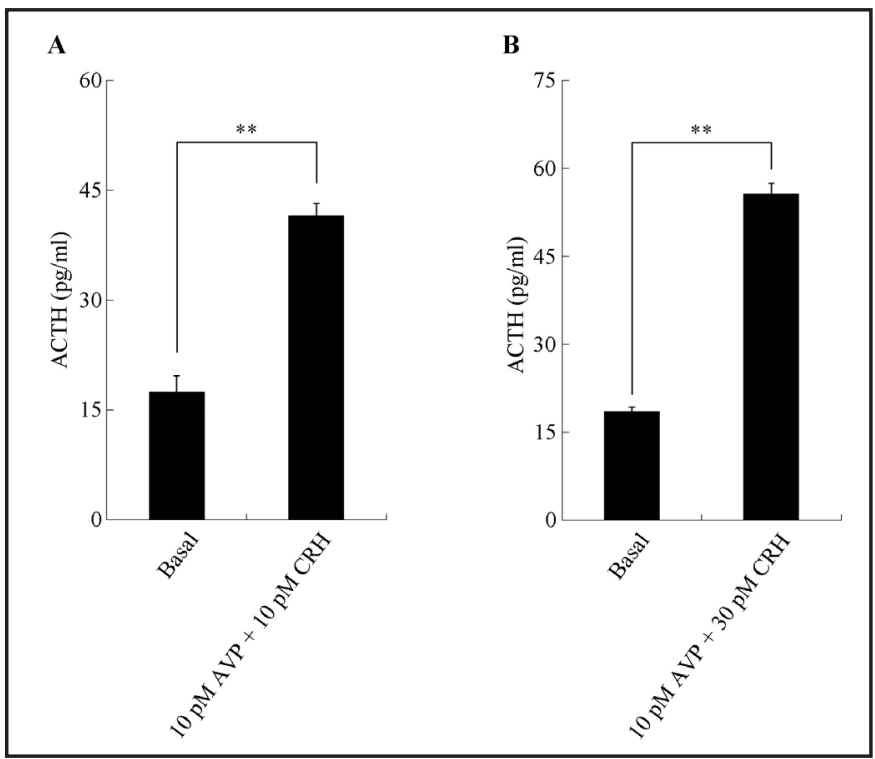


Fig. 4. Effect of AVP on CRH-stimulated ACTH secretion in anterior pituitary cells. Cells were perifused with serum-free medium before stimulation. After 30 minutes of collection of the baseline samples $(n=6)$, cells received constant stimulation with perifusion medium containing $\mathrm{CRH}$, with or without $10 \mathrm{pM}$ AVP. The time periods of the perifusion with CRH and AVP are shown by the clear box.

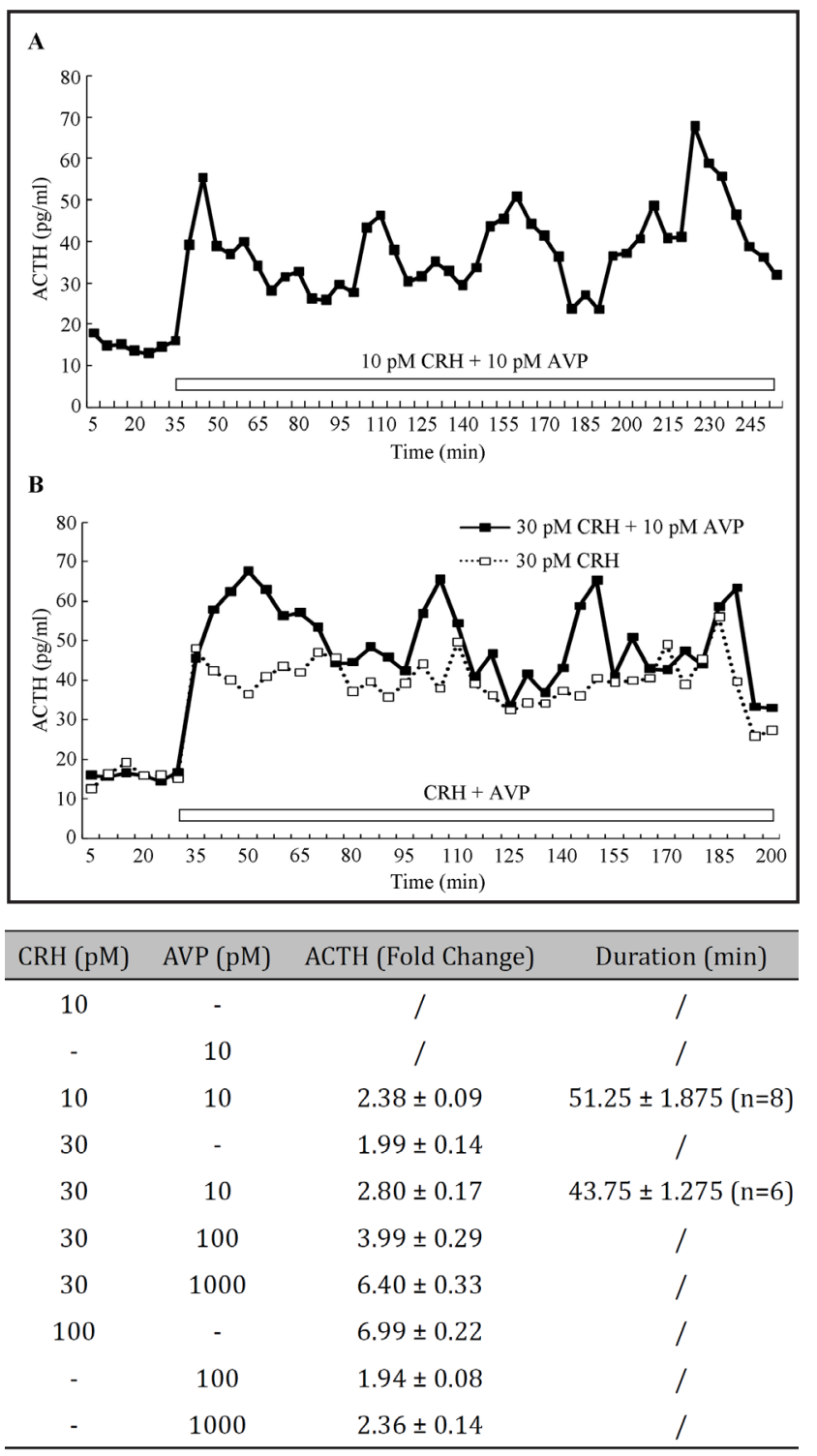

Table 1. ACTH secretion and pulsatility induced by CRH and AVP in the rat anterior pituitary perifusion system. Cells were perifused with serum-free medium before the addition of CRH and AVP. "-" represented no addition, and "/" no fold change or pulsatility. Fold change was expressed as the ACTH values under the stimulations divided by the basal line samples collected before treatment

\begin{tabular}{cccc}
\hline CRH (pM) & AVP (pM) & ACTH (Fold Change) & Duration (min) \\
\hline 10 & - & $/$ & $/$ \\
- & 10 & $/$ & $51.25 \pm 1.875(\mathrm{n}=8)$ \\
10 & 10 & $2.38 \pm 0.09$ & $/$ \\
30 & - & $1.99 \pm 0.14$ & $/$ \\
30 & 10 & $2.80 \pm 0.17$ & $43.75 \pm 1.275(\mathrm{n}=6)$ \\
30 & 100 & $3.99 \pm 0.29$ & $/$ \\
30 & 1000 & $6.40 \pm 0.33$ & $/$ \\
100 & - & $6.99 \pm 0.22$ & $/$ \\
- & 100 & $1.94 \pm 0.08$ & \\
- & 1000 & $2.36 \pm 0.14$ & \\
\hline
\end{tabular}

was $51.25 \pm 1.875$ minutes $(n=8)$. When we compared the patterns of ACTH secretion in anterior pituitary cells perifused with $30 \mathrm{pM}$ CRH, with or without $10 \mathrm{pM}$ AVP, we again found the same pulsatile ACTH secretion in the column with $30 \mathrm{pM}$ CRH and $10 \mathrm{pM}$ AVP. The duration of the pulsatility was $43.75 \pm 1.275$ minutes $(n=6)$. The ACTH secretion in the column perifused with constant 30 pM CRH was stable, with little pulsatility. (Fig. 4).

\section{Discussion}

In this study, a rat anterior pituitary cell perifusion system is successfully established in vitro. In this system, the physiological concentration of CRH and AVP are able to induce a pulsatile secretion of ACTH, and the duration of the pulsatility is very similar to that observed in vivo, the data obtained from the rat anterior pituitary perifusion system was shown in Table 1. This system will be helpful for studying the HPA axis activity and ACTH secretion.

It is generally recognized that CRH as well as AVP are synthesized by the neurons located in the dorsomedial parvocellular subdivision of the paraventricular nucleus (PVN) of the hypothalamus. A large body of evidence shows that AVP plays a role in regulating 


\section{Cellular Physiology Cell Physiol Biochem 2017;41:154-162

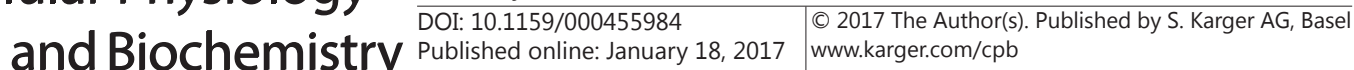 \\ Deng/Zhang/Wu: ACTH Pulsatility In Vitro}

pituitary corticoreoph $[1,16,17]$. A number of studies have shown that inhibition of vasopressinergic activity by the use of VP antibody or receptor antagonists can decrease ACTH and corticosterone responses to acute stress. Hypothalamic CRH and AVP released into the pituitary portal circulation gain access to receptors in the anterior pituitary cortcotroph cells, where they stimulate ACTH secretion. Unlike VP secreted into the peripheral circulation from magnocellular neurons, AVP responsible for corticotroph regulation is secreted from parvocellular axon terminals in the external zone of the median eminence [16]. In all species studied, including rat, mouse and human, a proportion of CRH-producing neurons express AVP, about $50 \%$ in basal conditions. And this proportion increases substantially during stress, especially chronic and prolonged adrenalectomy $[18,19]$. AVP is co-released with $\mathrm{CRH}$ and both contribute to ACTH secretion and activation of the HPA axis.

Using rat anterior pituitary cells perifused with the estimated basal pituitary portal circulation levels of $\mathrm{CRH}$ and AVP, the present study demonstrates that the pituitary corticotroph is sensitive to CRH and AVP pulses in the range of basal free circulation levels of these hormones. Preliminary experiments in a previous study indicated that 5 -minuteincreasing pulses of CRH resulted in concentration-dependent ACTH secretion with a threshold of $30 \mathrm{pM}$ [20]. In this study, the lowest physiological levels of CRH, 10pM was not able to produce a marked increase in ACTH secretion (Fig. 1). Actually, thirty picomolar of CRH increased ACTH by 2-fold, and the ACTH secretion was maintained stable for more than 2 hours with a continuous perifusion. A higher concentration of $100 \mathrm{pM}$ caused a 7 -fold increase, but the secretion started to decline 15 minutes later (data not shown), and this may due to the desensitization of the receptors under treatment with the stress level of hormone.

Continuous perifusion with $10 \mathrm{pM}$ AVP for up to 30 minutes did not alter ACTH secretion. Higher concentrations of AVP, specifically $100 \mathrm{pM}$ and $1 \mathrm{nM}$, caused a 1.94-fold and 2.36-fold increase in ACTH secretion, respectively. The increased ACTH was stable and lasted for more than 1 hour. These results indicated that AVP was a less potent agonist compared with CRH, agreed with the published papers $[1,7,8,16]$.

An experiment was designed to test the effect of AVP on ACTH secretion stimulated by $30 \mathrm{pM}$ CRH. In the cells perifused with continuous $30 \mathrm{pM}$ CRH, 5-minute increasing pulses of AVP resulted in concentration-dependent ACTH secretory peaks. This finding is consistent with Prickett's findings that the AVP pulse acts as an efficient stimulus on ACTH secretion in normal equine anterior pituitary cells in vitro when pre-incubated with CRH [21].

To determine the effect of CRH on AVP-stimulated ACTH secretion, rat anterior pituitary cells received continuous perifusion with $10 \mathrm{pM}$ AVP and CRH. These results showed that even the combination of the lowest physiological levels of CRH (10 pM) and AVP, caused a 2.38-fold increase, similar to the effect of the stimulation by $1 \mathrm{nM}$ AVP (2.36-fold).

The finding of a pulsatility in ACTH secretion by anterior pituitary cells receiving constant $10 \mathrm{pM}$ AVP with either $10 \mathrm{pM}$ or 30 pM CRH represents a very exciting discovery. Also, as we all known, ACTH released by the pituitary stimulates glucocorticoid secretion, and when it reaches sufficiently high levels it inhibits the pituitary corticotroph thus leading to the decrease of ACTH secretion, and the consequent decrease in glucocorticoid secretion. The group of Lightman in Bristol showed that low doses of CRH generates pulsatile corticosterone secretion in rats [22]. This finding is consistent with our results indicating that pulsatile corticosterone secretion resulted in ACTH pulsatility. Engler et al. also showed in 1990 that hypothalamic disconnection of the pituitary in sheep does not suppress the ultradian rhythm of corticosterone [23].

The duration of the pulsatility caused by $10 \mathrm{pM}$ CRH and $10 \mathrm{pM}$ AVP was about 50-55 minutes $(\mathrm{n}=8)$, and the duration of that caused by $30 \mathrm{pM}$ CRH and $10 \mathrm{pM}$ AVP was 40-45 minutes $(n=3)$. The latter was close to the physiological conditions reported by Veldhuis [11]. This indicated that the physiological levels of CRH and AVP were around $30 \mathrm{pM}$ and 10 pM, respectively.

The generator of the ACTH pulsatility remains unclear. Studies using Brattleboro rats or vasopreesion receptor gene knockout mice indicated that the ACTH secretion was unaltered in the absence of VP [24-26], but it was generally accepted that VP plays a role mediating 


\section{Cellular Physiology Cell Physiol Biochem 2017;41:154-162

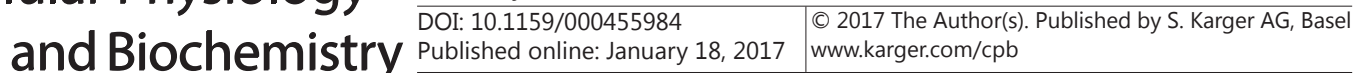 \\ Deng/Zhang/Wu: ACTH Pulsatility In Vitro}

ACTH responses [27-29]. As shown in Figure 4B, the cells in the column perifused with 30 $\mathrm{pM}$ CRH and 10pM AVP were more pulsatile compare to the cells in the column with $30 \mathrm{pM}$ CRH alone.

It has been shown that the actions of AVP was mediated by plasma membrane receptor $[30,31]$, and the receptor present in pituitary corticotroph is V1b receptor [32-35]. Aguilera's study showed that the regulation of $\mathrm{V} 1 \mathrm{~b}$ receptor plays an important role in the sensitivity of ACTH responses, maintaining the corticotroph responsiveness even in the presence of elevated glucocorticoid levels, but the expression of CRH and pituitary type $1 \mathrm{CRH}$ receptor were not changed or even reduced in conditions of high HPA activation [1]. A reported electrophysiological study supported that the circadian rhythmicity in the suprachiasmatic nuclei (SCN) neurons is independent of the afferent inputs from other brain areas [36]. Further study on single neuronal activity in the SCN revealed that the dorsomedial part of the SCN is an intrinsic oscillating pacemaker [37], Additionally, the dorsomedial part of SCN is also the main location of AVP neurons [12]. Moreover, the circadian rhythm persists despite a continuous infusion of CRH [38] or AVP, suggesting that CRH or AVP alone is not the mediator of ACTH pulses. Actually, a study discovered a circadian rhythm in AVP RNA expression and the loss of the circadian rhythm of AVP RNA expression was shown in the transgenic CLOCK knockout mice [13].

In this study, a rat anterior pituitary cells perifusion model was used to examine the ACTH secretory patterns regulated by CRH and AVP. CRH and AVP in the physiological range cause marked increase in ACTH secretion, and potentiate the effect of each other on ACTH secretion. Under constant perifusion with a combination of low levels of AVP and CRH, cells were able to produce pulsatile ACTH secretion. Accordingly, we can draw the conclusion that CRH and AVP are essential for the ACTH pulsatility, and AVP acts like a switch of the pulsatility. However, the underlying mechanisms need to be further investigated.

\section{Acknowledgements}

This study was supported by Grants from China Postdoctoral Science Foundation (2016M590798), Natural Science Foundation of Guangdong Province, China (2016A030310071), the Science and Technology Planning Project of Shenzhen Municipality, China ( JCYJ20160428171238706) and the Health and Family Planning Commission Project of Shenzhen Municipality, China (201605017).

\section{Disclosure Statement}

The authors have nothing to disclose.

\section{References}

1 Aguilera G: Regulation of pituitary ACTH secretion during chronic stress. Front Neuroendocrinol 1994;15:321-350.

2 Antoni FA: Hypothalamic control of adrenocorticotropin secretion: advances since the discovery of 41-residue corticotropin-releasing factor. Endocr Rev 1986; 7:351-378.

-3 Kabir NN, Kazi JU: Grb10 is a dual regulator of receptor tyrosine kinase signaling. Mol Biol Rep 2014;41:1985-1992.

-4 Vale W, Rivier C, Brown MR, Spiess J, Koob G, Swanson L, Bilezikjian L, Bloom F, Rivier J: Chemical and biological characterization of corticotropin releasing factor. Recent Prog Horm Res 1983;39:245-270.

-5 Autelitano DJ, Lundblad JR, Blum M, Roberts JL: Hormonal regulation of POMC gene expression. Annu Rev Physiol 1989;51:715-726. 


\section{Cellular Physiology Cell Physiol Biochem 2017;41:154-162

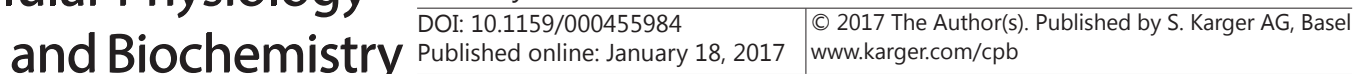 \\ Deng/Zhang/Wu: ACTH Pulsatility In Vitro}

6 Bale TL, Vale WW: CRF and CRF receptors: role in stress responsivity and other behaviors. Annu Rev Pharmacol Toxicol 2004;44:525-557.

7 Abou-Samra AB, Harwood JP, Manganiello VC, Catt KJ, Aguilera G: Phorbol 12-myristate 13-acetate and vasopressin potentiate the effect of corticotropin-releasing factor on cyclic AMP production in rat anterior pituitary cells. Mechanisms of action. J Biol Chem 1987;262:1129-1136.

8 Gillies GE, Linton EA, Lowry PJ: Corticotropin releasing activity of the new CRF is potentiated several times by vasopressin. Nature 1982;299:355-357.

-9 Aguilera G, Pham Q Rabadan-Diehl C: Regulation of pituitary vasopressin receptors during chronic stress: relationship to corticotroph responsiveness. J Neuroendocrinol 1994;6:299-304.

10 Levin N, Blum M, Roberts JL: Modulation of basal and corticotropin-releasing factor-stimulated proopiomelanocortin gene expression by vasopressin in rat anterior pituitary. Endocrinology 1989;125:2957-2966.

11 Veldhuis JD, Iranmanesh A, Johnson ML, Lizarralde G: Amplitude, but not frequency, modulation of adrenocorticotropin secretory bursts gives rise to the nyctohemeral rhythm of the corticotropic axis in man. J Clin Endocrinol Metab 1990;71:452-463.

12 Yamase K, Takahashi S, Nomura K, Haruta K, Kawashima S: Circadian changes in arginine vasopressin level in the suprachiasmatic nuclei in the rat. Neurosci Lett 1991;130:255-258.

13 Jin X, Shearman LP, Weaver DR, Zylka MJ, de Vries GJ, Reppert SM: A molecular mechanism regulating rhythmic output from the suprachiasmatic circadian clock. Cell 1999;96:57-68.

14 Plotsky PM, Vale W: Hemorrhage-induced secretion of corticotropin-releasing factor-like immunoreactivity into the rat hypophysial portal circulation and its inhibition by glucocorticoids. Endocrinology 1984;114:164-169.

15 Fink G, Robinson IC, Tannahill LA: Effects of adrenalectomy and glucocorticoids on the peptides CRF-41, AVP and oxytocin in rat hypophysial portal blood. J Physiol 1988;401:329-345.

-16 Antoni FA: Vasopressinergic control of pituitary adrenocorticotropin secretion comes of age. Front Neuroendocrinol 1993;14:76-122.

17 Mc CS, Brobeck JR: Evidence for a role of the supraopticohypophyseal system in regulation of adrenocorticotrophin secretion. Proc Soc Exp Biol Med 1954;87:318-324.

18 Whitnall MH: Regulation of the hypothalamic corticotropin-releasing hormone neurosecretory system. Prog Neurobiol 1993;40:573-629.

19 de Goeij DC, Kvetnansky R, Whitnall MH, Jezova D, Berkenbosch F, Tilders FJ: Repeated stress-induced activation of corticotropin-releasing factor neurons enhances vasopressin stores and colocalization with corticotropin-releasing factor in the median eminence of rats. Neuroendocrinology 1991;53:150-159.

20 Deng Q Riquelme D, Trinh L, Low MJ, Tomic M, Stojilkovic S, Aguilera G: Rapid Glucocorticoid Feedback Inhibition of ACTH Secretion Involves Ligand-Dependent Membrane Association of Glucocorticoid Receptors. Endocrinology 2015;156:3215-3227.

-21 Prickett TCR, Inder WJ, Evans MJ, Donald RA: Interleukin-1 potentiates basal and AVP-stimulated ACTH secretion in vitro--the role of CRH pre-incubation. Horm Metab Res 2000;32:350-354.

-22 Walker JJ, Spiga F, Waite E, Zhao Z, Kershaw Y, Terry JR, Lightman SL: The origin of glucocorticoid hormone oscillations. PLoS Biol 2012;10:e1001341.

-23 Engler D, Pham T, Liu JP, Fullerton MJ, Clarke IJ, Funder JW: Studies of the regulation of the hypothalamicpituitary-adrenal axis in sheep with hypothalamic-pituitary disconnection. II. Evidence for in vivo ultradian hypersecretion of proopiomelanocortin peptides by the isolated anterior and intermediate pituitary. Endocrinology 1990;127:1956-1966.

24 Wersinger SR, Ginns EI, O'Carroll AM, Lolait SJ, Young WS, 3rd: Vasopressin V1b receptor knockout reduces aggressive behavior in male mice. Mol Psychiatry 2002; 7:975-984.

25 Makara GB, Mergl Z, Zelena D: The role of vasopressin in hypothalamo-pituitary-adrenal axis activation during stress: an assessment of the evidence. Ann N Y Acad Sci 2004;1018:151-161.

26 Tanoue A, Ito S, Honda K, Oshikawa S, Kitagawa Y, Koshimizu TA, Mori T, Tsujimoto G: The vasopressin V1b receptor critically regulates hypothalamic-pituitary-adrenal axis activity under both stress and resting conditions. J Clin Invest 2004;113:302-309.

27 Rivier J, Rivier C, Vale W: Synthetic competitive antagonists of corticotropin-releasing factor: effect on ACTH secretion in the rat. Science 1984;224:889-891. 


\section{Cellular Physiology Cell Physiol Biochem 2017;41:154-162

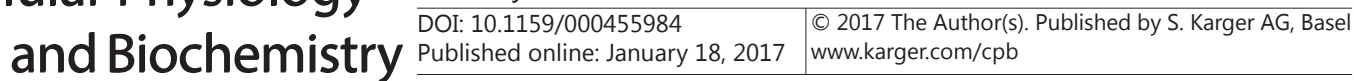 \\ Deng/Zhang/Wu: ACTH Pulsatility In Vitro}

-28 Olsen L, Knigge U, Warberg J: Gastrin-releasing peptide stimulation of corticotropin secretion in male rats. Endocrinology 1992;130:2710-2716.

29 Suda T, Nakano Y, Tozawa F, Sumitomo T, Sato Y, Yamada M, Demura H: The role of corticotropin-releasing factor and vasopressin in hypoglycemia-induced proopiomelanocortin gene expression in the rat anterior pituitary gland. Brain Res 1992;579:303-308.

-30 Jard S, Barberis C, Audigier S, Tribollet E: Neurohypophyseal hormone receptor systems in brain and periphery. Prog Brain Res 1987;72:173-187.

-31 Peter J, Burbach H, Adan RA, Lolait SJ, van Leeuwen FW, Mezey E, Palkovits M, Barberis C: Molecular neurobiology and pharmacology of the vasopressin/oxytocin receptor family. Cell Mol Neurobiol 1995;15:573-595.

- 32 Seibold A, Brabet P, Rosenthal W, Birnbaumer M: Structure and chromosomal localization of the human antidiuretic hormone receptor gene. Am J Hum Genet 1992;51:1078-1083.

-33 Sugimoto T, Saito M, Mochizuki S, Watanabe Y, Hashimoto S, Kawashima H: Molecular cloning and functional expression of a cDNA encoding the human V1b vasopressin receptor. J Biol Chem 1994;269:27088-27092.

34 Lolait SJ, O'Carroll AM, Brownstein MJ: Molecular biology of vasopressin receptors. Ann N Y Acad Sci 1995;771:273-292.

35 Lolait SJ, O'Carroll AM, Mahan LC, Felder CC, Button DC, Young WS, 3rd, Mezey E, Brownstein MJ: Extrapituitary expression of the rat V1b vasopressin receptor gene. Proc Natl Acad Sci USA 1995;92:67836787.

-36 Inouye ST, Kawamura H: Persistence of circadian rhythmicity in a mammalian hypothalamic "island" containing the suprachiasmatic nucleus. Proc Natl Acad Sci USA 1979;76:5962-5966.

-37 Shibata S, Liou S, Ueki S, Oomura Y: Influence of environmental light-dark cycle and enucleation on activity of suprachiasmatic neurons in slice preparations. Brain Res 1984;302:75-81.

- 38 Ur E, Capstick C, McLoughlin L, Checkley S, Besser GM, Grossman A: Continuous administration of human corticotropin-releasing hormone in the absence of glucocorticoid feedback in man. Neuroendocrinology 1995;61:191-197. 